\title{
Synthesis
}

\section{Enabling Effective Problem-oriented Research for Sustainable Development}

\author{
Christoph Kueffer ${ }^{1}$, Evelyn Underwood ${ }^{2}$, Gertrude Hirsch Hadorn ${ }^{3}$, Rolf Holderegger ${ }^{1,4}$, Michael Lehning ${ }^{5,6}$, Christian Pohl \\ ${ }^{3}$, Mario Schirmer $^{7}$, René Schwarzenbach ${ }^{8}$, Michael Stauffacher ${ }^{3}$, Gabriela Wuelser $^{3}$ and Peter Edwards ${ }^{1,2}$
}

\begin{abstract}
Environmental problems caused by human activities are increasing; biodiversity is disappearing at an unprecedented rate, soils are being irreversibly damaged, freshwater is increasingly in short supply, and the climate is changing. To reverse or even to reduce these trends will require a radical transformation in the relationship between humans and the natural environment. Just how this can be achieved within, at most, a few decades is unknown, but it is clear that academia must play a crucial role. Many believe, however, that academic institutions need to become more effective in helping societies move toward sustainability. We first synthesize current thinking about this crisis of research effectiveness. We argue that those involved in producing knowledge to solve societal problems face three particular challenges: the complexity of real-world sustainability problems, maintaining impartiality when expert knowledge is used in decision making, and ensuring the salience of the scientific knowledge for decision makers. We discuss three strategies to meet these challenges: conducting research in interdisciplinary teams, forming research partnerships with actors and experts from outside academia, and framing research questions with the aim of solving specific problems (problem orientation). However, we argue that implementing these strategies within academia will require both cultural and institutional change. We then use concepts from transition management to suggest how academic institutions can make the necessary changes. At the level of system optimization, we call for: quality criteria, career incentives, and funding schemes that reward not only disciplinary excellence but also achievements in inter-/transdisciplinary work; professional services and training through specialized centers that facilitate problem-oriented research and reciprocal knowledge exchange with society; and the integration of sustainability and inter-/transdisciplinary research practices into all teaching curricula. At the level of system innovation, we propose radical changes in institutional structures, research and career incentives, teaching programs, and research partnerships. We see much value in a view of change that emphasizes the complementarity of system innovation and system optimization. The goal must be a process of change that preserves the traditional strengths of academic research, with its emphasis on disciplinary excellence and scientific rigor, while ensuring that institutional environments and the skills, worldviews, and experiences of the involved actors adapt to the rapidly changing needs of society.
\end{abstract}

Key Words: interdisciplinarity; knowing-doing gap; outreach; participation; post-normal science; problem-oriented research; research partnership; research policy; science-policy nexus; social learning; transdisciplinarity; transition management

\section{INTRODUCTION}

Two of the important achievements of science have been to document and understand the impacts that humans have on the global ecosystem. Many studies in recent years have shown, in ever greater detail, that the world is living beyond its means. Thanks to the collective efforts of natural scientists, we know, for example, that biodiversity is being lost at an increasing rate, that soils are being irreversibly damaged, that freshwater is being polluted or used faster than it is replenished in many regions, and that the climate is changing (Millennium Ecosystem Assessment 2005, IPCC 2007, McIntyre et al. 2009, WWAP 2009, Schwarzenbach et al. 2010). Thanks to the work of social scientists, we have a good understanding of the societal context of these sustainability problems, and their social and economic consequences (Rayner and Malone 1998, Becker et al. 1999, Costanza 2003). Through their work, we know that such problems are caused by the combined actions of diverse societal actors, that the people they most affect are usually not those who caused them, and that these problems are multi-dimensional, complex, and politically controversial.

Given this complexity, the goal of sustainable development seems to many to be further away now than when the concept was formulated in 1987 (World Commission on Environment and Development 1987). Indeed, no one knows how sustainability can be achieved. What is certain is that it will be difficult and entail a hugely complex process of adaptive management, with scientists involved at all stages: detecting emerging problems, designing and implementing specific measures, monitoring the consequences, and drawing lessons for the future (ICSU 2010). It will also require innovation: new technologies, new infrastructures, different business models, new regulatory frameworks, altered value systems, and changed patterns of consumption. Thus, academic institutions will have a central role to play in helping societies live more sustainably.

\footnotetext{
${ }^{1}$ Institute of Integrative Biology, ETH Zurich, ${ }^{2}$ Alliance for Global Sustainability, ETH Zurich, ${ }^{3}$ Institute for Environmental Decisions, ETH Zurich, ${ }^{4}$ WSL Swiss Federal Research Institute, ${ }^{5}$ WSL Institute for Snow and Avalanche Research, ${ }^{6}$ École Polytechnique Fédérale de Lausanne (EPFL), ${ }^{7}$ Eawag,

${ }^{8}$ Competence Center Environment and Sustainability (CCES), ETH Zurich
} 
However, many argue that academic institutions should be doing more (Lubchenco 1998, Klein et al. 2001, Gallopín et al. 2002, McMichael et al. 2003, Samarasekera 2009, ICSU 2010, Levin and Clark 2010, Chapin et al. 2011). These critical voices point out that science has often been late or ineffective in preventing or mitigating emerging risks (Harremoës et al. 2001) and that even the well-known environmental problems such as biodiversity loss and climate change remain unsolved (Raven 2002, McMichael et al. 2003). The reasons for this gap between knowledge production and action, however, are complex and not easy to address (Pullin et al. 2004, van Kerkhoff and Lebel 2006, Shanley and López 2009). Some reasons relate to the conservative nature of academic institutions, which are often slow to change their practices and adopt new modes of research and outreach (Rhoten and Parker 2004, Nightingale and Scott 2007).

This article is based on a workshop that was convened to discuss how research institutions can become more effective in supporting sustainable development. The workshop brought together scientists involved in sustainability research from both basic and applied research institutions, as well as experts in theory of science and institutional change at academic institutions. It revealed that each of these three groups, i.e., practicing scientists, experts on new research practices, and university administrators involved in enabling institutional change, has accumulated a broad knowledge base and experience related to effective problem-oriented research for sustainable development, but that the heterogeneity and breadth of concepts and notions hinder learning and consensus building among different actors involved in sustainability at academic institutions.

Here, therefore, we analyze the perceived crisis of research effectiveness and consider how it can be overcome. We divide our analysis into three sections. First, we discuss some of the special features of sustainability problems that pose particular challenges for sustainability research and problem solving. Next, we describe coping strategies for research, i.e., interdisciplinarity, partnerships, and problem orientation, which are widely considered to help overcome these challenges. Finally, we discuss the practical steps that academic institutions can take to promote their effectiveness in tackling real-world problems of sustainability. Thereby, we distinguish between fine-tuning and adapting the existing system (system optimization) and aiming at system changes (system innovation).

We draw not only upon the experiences and expertise of the workshop participants, but also upon a rapidly growing literature about the relationships between science and society, and the potential of new modes of research to improve realworld problem solving (Nowotny et al. 2001, Scholz and Tietje 2002, Cash et al. 2003, Bammer 2005, COSEPUP 2005, Eigenbrode et al. 2007, Kueffer et al. 2007, Pohl and Hirsch
Hadorn 2007, Hirsch Hadorn et al. 2008, Frodeman et al. 2010, Groffman 2010, Wuelser et al. 2012), as well as upon literature on institutional change for sustainability at academic institutions (Sterling 2004, Beringer and Adomßent 2008, Miller et al. 2008, Sherman 2008, Crow 2010, Ferrer-Balas et al. 2010, Rusinko 2010, Stephens and Graham 2010, Brundiers and Wiek 2011, Krasny et al. 2011). Our aim is to provide a synthetic overview of this literature for an interdisciplinary and implementation-oriented readership. We therefore bring together and systematize concepts and results from diverse research fields, including science and technology studies (Nowotny et al. 2001, Cash et al. 2003), theory of inter- and transdisciplinarity (Pohl and Hirsch Hadorn 2007, Hirsch Hadorn et al. 2008, Frodeman et al. 2010), resilience theory (Moore and Westley 2011), organization science (March 1991), and transition management (Rotmans et al. 2001, Miller et al 2008).

\section{COMPLEXITY, IMPARTIALITY, AND SALIENCE CHALLENGES}

In tackling problems of sustainability, research is important in at least three ways: for understanding the causes and effects that determine the system dynamics of the problem, for clarifying conflicts of interests and value systems, and for contributing to the development of appropriate means for action (ProClim 1997, Grunwald 2004, Pohl and Hirsch Hadorn 2007, Kueffer and Hirsch Hadorn 2008). However, real-world problems have general characteristics that not only complicate the process of doing research, but may hinder the application of research findings. We call these the challenges of complexity, impartiality, and salience, and describe them briefly in the following paragraphs (Cash et al. 2003, Hirsch Hadorn et al. 2008, Kueffer and Hirsch Hadorn 2008; Fig. 1).

The complexity challenge arises because tackling sustainability problems usually requires expertise, not only from a wide range of academic disciplines, but also from outside academia (Kates et al. 2001, Miller et al. 2008). Such problems, therefore, cannot be investigated by the usual methods and approaches of disciplinary research. Indeed, if we do treat these problems from the perspective of a single discipline, the results are unlikely to be useful (e.g., Harremoës et al. 2001). A related difficulty is that sustainability problems usually span broad spatial and temporal scales, making it difficult or impossible to investigate them experimentally. We therefore need to find new approaches for integrating different types of data and for simulating the likely behavior of complex systems (Shrader-Frechette and McCoy 1993, Schellnhuber 1999, Miller et al. 2008, Plowright et al. 2008, Khagram et al. 2010). However, because such systems often exhibit highly nonlinear behavior, with numerous feedbacks and thresholds (Gunderson and Holling 2002), accurate prediction of their behavior may prove impossible. For this reason, new approaches are needed to determine the validity of results and help interpret uncertainty (Holling 1978, Shrader-Frechette 
and McCoy 1993, Nowotny et al. 2001, Hoffmann-Riem and Wynne 2002, Sutherland et al. 2004, Carpenter et al. 2009, Gross 2010).

Fig. 1. A conceptual framework of a transitional change of academic culture toward more effective knowledge production. We see three fundamental challenges: complexity, impartiality, and salience, which impede effective research for sustainable development. We argue that overcoming these challenges will require a transitional change of academic culture that builds on three interrelated coping strategies, namely a move toward increased problem orientation and associated increased interdisciplinarity and research partnerships. Problem orientation means that the real-world problems of actors should designate theory, methods, collaborations between disciplines, and research partnerships, not the reverse, in marked contrast to discipline-based inquiry.

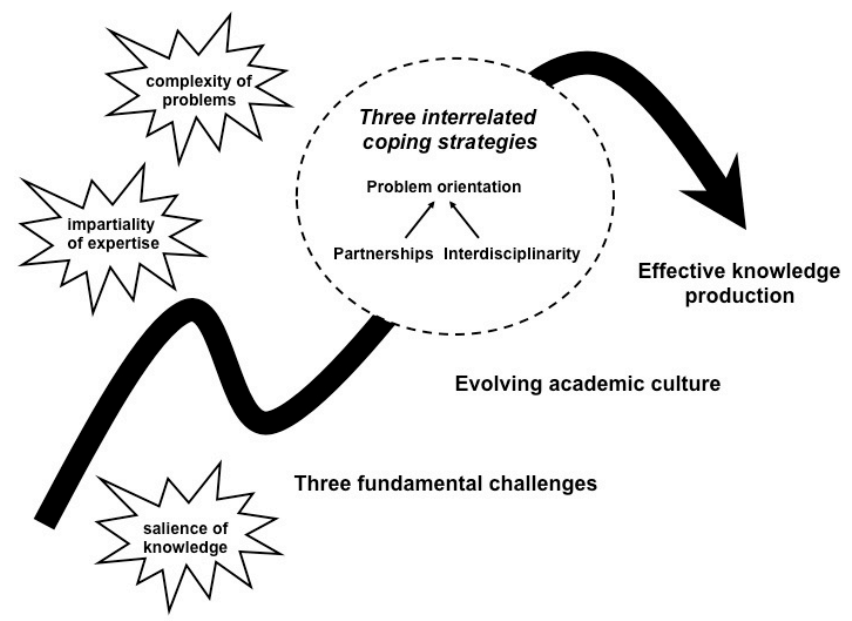

The impartiality challenge highlights the difficulty of ensuring that research serves the common interest, as expressed by the goals of sustainable development (World Commission on Environment and Development 1987), rather than the particular interests of some group. Indeed, interest groups may decisively influence the framing of the research problem, the scope of the work undertaken, and how the results are interpreted and used. This challenge is greatest in the case of problems for which any information is inherently uncertain and for which different stakeholders have strongly diverging interests or value systems (Funtowicz and Ravetz 1993, Pielke 2007). In these cases, which are typical of many sustainability problems, it may be impossible to separate clearly the process of producing facts from the process of interpreting them in support of a particular decision. This does not diminish the role of experts in producing the best possible knowledge (Collins and Evans 2007); rather, it gives them an additional responsibility, as those who have grappled most intensively with a problem, in helping decision makers to interpret this knowledge. A common problem in these cases is that different experts come to different conclusions. This may simply be because evaluating uncertain knowledge is to some extent a process of estimating, balancing, and deliberating upon the information at hand. However, there is also the risk that information will be used selectively or misused to promote the interests of particular stakeholders (Funtowicz and Ravetz 1993, Sarewitz 2004, Pielke 2007, Oreskes and Conway 2010). Notorious examples have concerned attempts to deny the health effects of tobacco (Michaels 2008) or to downplay the problem of climate change (Kitcher 2010). In such cases, additional scientific facts may even reduce the chances of reaching a consensus and thus hinder the search for a solution (Sarewitz 2004). To help remove these impediments to effective decision making, many authors have called for the establishment of guiding principles that help both experts and decision makers in assessing and using scientific knowledge that is either incomplete or characterized by uncertainty (Hoffmann-Riem and Wynne 2002, Jasanoff 2007, Pielke 2007, Giller et al. 2008, van der Sluijs et al. 2008, Wibeck 2009).

The salience challenge refers to the importance of providing scientific knowledge in a form that can be used easily in making decisions (Cash et al. 2003). All too often, information that would be highly relevant to a decision is not used, either because it is inaccessible or because its importance is not evident. This can happen for many reasons: potential users may simply be unaware that certain information exists, it may cost too much time or money to obtain it, or it may be incomprehensible without the help of specialists. As a consequence, many management decisions are taken without using available scientific evidence, as has been shown for decision making in nature conservation management (Pullin et al. 2004, Shanley and López 2009, Cook et al. 2010) and health technology transfer (Simiyu et al. 2010). The challenge for scientists, therefore, is to frame both knowledge and the processes of generating and interpreting knowledge to provide answers to the questions that are relevant to decision makers (Hirsch 1995, Eigenbrode et al. 2007, McNie 2007, Hirsch Hadorn et al. 2008, Wuelser et al. 2012).

\section{STRATEGIES FOR COPING: INTERDISCIPLINARITY, PARTNERSHIPS, AND PROBLEM ORIENTATION}

To meet these three challenges of sustainability research, three related strategies are commonly recommended. These strategies are: to conduct research in interdisciplinary teams, to form research partnerships with actors and experts from outside academia, and to frame research questions with the aim of solving specific problems (Fig. 1). In each of these strategies, the organizing principle is problem orientation, which means that the research process is determined by the collaborations needed to solve a specific problem; these may 
involve not only various disciplines but also actors and experts from outside of academia.

\section{Interdisciplinarity}

Because of their complexity, most sustainability problems cannot be tackled from the perspective of a single discipline but require an appropriate balance between engineering, natural sciences, and social sciences (ICSU 2010). Indeed, when scientists are tempted to take a disciplinary focus, they run the risk of interpreting the problem too narrowly, and their proposed solution is unlikely to be adequate (Harremoës et al. 2001, Kriebel et al. 2001, McMichael et al. 2003, Kueffer 2010). As Brewer (1999:328) remarked, "the world has problems, but universities have departments."

Interdisciplinarity has been defined as "a mode of research that integrates information, data, techniques, tools, perspectives, concepts, and/or theories from two or more disciplines or bodies of specialized knowledge to solve problems whose solutions are beyond the scope of a single discipline" (COSEPUP 2005:2). Interdisciplinarity can be implemented at the level of individual researchers, research teams, projects and programs, academic institutions, or research fields (COSEPUP 2005, Jacobs and Frickel 2009, Frodeman et al. 2010). Given good collaboration, interdisciplinary research offers the best prospect of producing answers to sustainability problems that are perceived as salient (as outlined later in Strategies for Coping: Interdisciplinarity, Partnerships, and Problem Orientation: Problem orientation) and enjoy broad legitimacy. However, the difficulties of such collaboration should not be underestimated (COSEPUP 2005), especially between the natural and social sciences (Pohl 2005, Lowe et al. 2009, Strang 2009). Building an effective interdisciplinary team requires clearly defined common goals, excellent communication, and time to develop shared understanding of the different perspectives and their potential for the common purpose (Giri 2002, Loibl 2006, Evely et al. 2008, Thompson 2009). Hence, interdisciplinarity is not a panacea solution to all complex problems, but complements disciplinary research.

\section{Partnerships}

The second important strategy is to work in close collaboration with partners from outside academia; depending on the problem, these could be decision makers, stakeholders or nonacademic experts from civil society or the private or public sectors. This form of collaboration is often described as transdisciplinary (Klein et al. 2001), but we use the term partnership here to emphasize that sustainability research benefits greatly from enduring relationships among complementary partners (Cash et al. 2003, Kueffer 2006, Roux et al. 2006, Pohl and Hirsch Hadorn 2007, Dietz and Stern 2008, Fry et al. 2008, Barreteau et al. 2010).

The involvement of stakeholders and decision makers helps ensure that research questions are formulated in a way that is relevant to their needs. The inclusion of nonacademic experts contributes greatly to the knowledge base, especially when it comes to solving practical problems (Bagamoyo College of Arts et al. 2002, Hubert et al. 2008, Schelling et al. 2008). Unfortunately, many transdisciplinary teams only work together for a restricted time period that is usually determined by project funding. While this is often unavoidable, the full benefit of collaboration, in particular in producing knowledge that is salient to the needs of actors, is most likely to come from longer-term partnerships (see examples in Hirsch Hadorn et al. 2008).

\section{Problem orientation}

Finding the right answer depends upon asking the right question. In sustainability research, problem orientation means the quest to formulate research questions that are most likely to provide the answers that actors need (Gibbons et al. 1994, Hirsch 1995, Brewer 1999, Pohl and Hirsch Hadorn 2007, Kueffer and Hirsch Hadorn 2008). Thus, the problem to be solved determines the appropriate conceptual framework, which should include goal definition, an understanding of relevant societal processes, appropriate methods, and appropriate forms of partnership (Pohl et al. 2010, Wuelser et al. 2012). This approach is in marked contrast to that of most discipline-based inquiry, in which the questions or hypotheses usually emerge from a particular theoretical framework. However, even with the problem clearly defined, the research must find a balance between understanding the system dynamics, clarifying and solving conflicts of interests, and developing actual solutions (e.g., Pohl and Hirsch Hadorn 2007, Kueffer and Hirsch Hadorn 2008).

An essential feature of problem-oriented research is that the resulting solutions depend upon how the problem is framed. In other words, the framing of the problem has a performative role that determines the options that are eventually presented to decision makers (Rittel and Webber 1973, Elzinga 2008, Kueffer and Hirsch Hadorn 2008, Pohl 2011). For some clearly defined problems, it may be obvious from the beginning that a particular type of expertise is required, and the proposed solution would be widely legitimated. However, most sustainability problems are too complex, and the required solution is not at first evident. Consider, for example, a regional administration that wishes to make a contribution toward tackling anthropogenic climate change. Such a complex problem could, in principle, be approached in several ways. For example, an automobile engineer might focus on improving the fuel-efficiency of vehicles; an urban planner might aim to optimize traffic flow; and a landscape ecologist might propose to develop ecosystems with a high carbon storage capacity. Each of these research activities might produce valuable results, but together, they are unlikely to represent the most effective solution. Not only do they fail to consider the complexity of the problem, but the proposed solutions may be regarded as irrelevant by some stakeholders 
(i.e., not salient). Even worse, some solutions might turn out to have negative impacts for carbon emissions. If the traffic flows more freely, for example, people may choose to make longer journeys and so consume more fossil fuel. This would be an example of the rebound effect that can negate attempts toward greater sustainability. A better approach would be for the engineer, urban planner, and ecologist to work together in partnership with stakeholders. Such a process might produce a more radical planning concept, for example, traffic-free urban areas, energy-efficient public transport, and green corridors for recreation, that not only meets the goal of reducing carbon emissions, but also improves the quality of the urban environment. In this way, a problem-oriented approach could provide a solution that is both more effective in meeting the primary goal and also more acceptable to the population.

\section{CREATING AN ENABLING ACADEMIC ENVIRONMENT FOR EFFECTIVE RESEARCH FOR SUSTAINABLE DEVELOPMENT}

To encourage scientists to become involved in problemoriented research, changes are needed in how academic institutions are managed, organized, and funded (Rhoten and Parker 2004, COSEPUP 2005, Hirsch Hadorn et al. 2008, Schneidewind 2009, Shanley and López 2009, Frodeman et al. 2010, Groffman 2010). These changes can either be achieved through a gradual evolution from existing structures or through more radical system change (Miller et al. 2008, Sherman 2008, Crow 2010, Rusinko 2010). Earlier work on organizational learning portrayed these alternatives as a tradeoff between "exploration of new possibilities" and "exploitation of old certainties" (March 1991). In the language of transition management, these alternatives represent system optimization, i.e., optimizing existing elements and adding new elements, and system innovation, which entails a more fundamental transformation of the structure to meet new challenges (Rotmans et al. 2001). Indeed, some authors have used such a systems framework to explore how fundamental system-wide changes of the university system can be triggered (Miller et al. 2008, Stephens and Graham 2010). We use this dichotomy in discussing some of the practical measures that academic institutions can take to create an effective enabling environment for research related to sustainable development (Fig. 2).

\section{Develop new criteria and ways to assess the quality and impact of problem-oriented research}

Evaluation plays a central role in academic life. It is the basis for accepting manuscripts for publication, distributing research funding, promoting staff, hiring new staff, and planning new strategic initiatives. The standard procedures for academic evaluation are based upon peer review, which means assessment by colleagues from the same specialized research community. However, these procedures are often ineffective for assessing the quality of problem-oriented research because they fail to take account of the special demands of inter- and transdisciplinary research. For this reason, there have been many calls to adapt and expand the classical approaches (COSEPUP 2005, Donovan 2007, Stoll-Kleemann and Pohl 2007, Klein 2008, Holbrook 2009, Frodeman et al. 2010) so as to involve a broader range of interdisciplinary and nonacademic experts.

Fig. 2. Creating an enabling environment for effective sustainability research at universities. Universities might change incentive systems and adapt quality criteria for evaluating job applications and grant proposals for research funding, and push to change peer review of scientific performance. Universities can also build up research capacities for increased problem orientation, interdisciplinarity, and partnerships. First, professional services (comparable to technology transfer offices or corporate communication units) aid researchers through professional advice and training. Second, institutional structures may be changed, e.g., through the formation of interdisciplinary research departments. Third, students and researchers may be educated to develop the particular skills needed for novel types of research activities. Outreach needs to change from unidirectional knowledge transfer to reciprocal knowledge exchange. Each of these changes can be implemented at the level of system optimization (fine tuning and adapting the existing system) or system innovation (fundamental system changes).

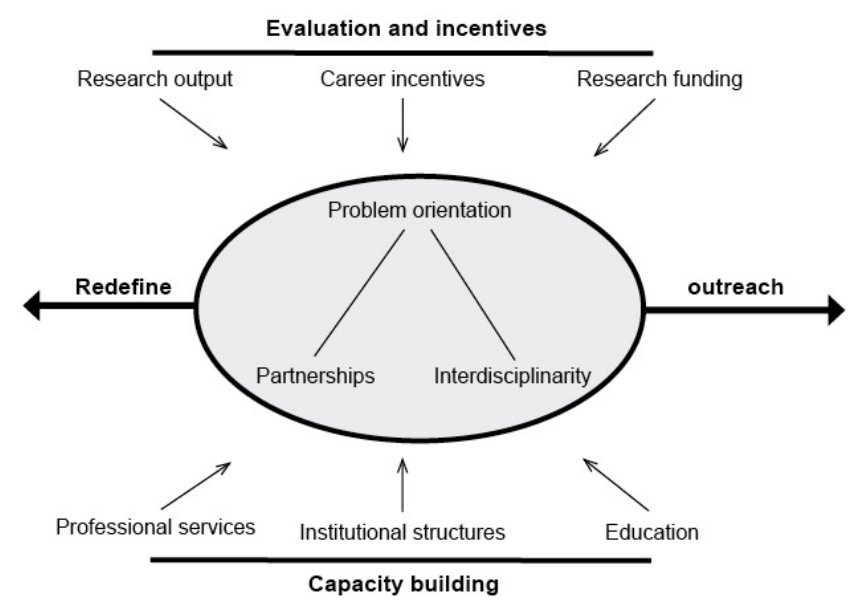

This new approach needs to account for the following three aspects: (1) the novel research process, e.g., the range and intensity of inter- and transdisciplinary interactions and the importance of a problem-framing phase; (2) the particular qualities of inter- and transdisciplinary scientific inquiry and innovation, e.g., research scope and problem orientation, the diversity of enquiry and outputs, the potential to challenge 
existing solutions, and the novelty of methods and concepts; and (3) the likely benefits in application and the quality of outreach, e.g., provision of specific examples and explanations for applications, license agreements and patents, nonacademic reports or guidelines and policy briefs, media releases, nonacademic training, evidence of partnership with government agencies or the private sector, and stakeholder awareness and satisfaction.

System optimization and system innovation differ in the weight they give to these new criteria (Huutoniemi 2010). In system optimization, new criteria to assess the project's broader impact are added to complement the existing procedures related to academic merit, e.g., the broader impact criterion proposed by the U.S. National Science Foundation (Holbrook 2010). In system innovation, the goal of assessment is changed more fundamentally, giving priority to assessing a project in terms of its societal impacts and benefits to the common good.

\section{Create new career incentives and opportunities}

The choices that scientists make about what to study and how to allocate their time are strongly influenced by the many factors, both formal and informal, that constitute the incentive system. Particularly important are the criteria that employers use to make appointments and promotions and to evaluate individual performance. Because the most important of these is usually success in academic publishing, scientists are under great pressure to publish their work as effectively as possible; indeed, achieving high bibliometric impact becomes the principal aim of many scientists. Although other forms of recognition, such as appreciation by peers and knowledge users, academic prizes, and student interest can also be important motivations for scientific work, these are less significant in terms of academic career. In such a onedimensional evaluation system, with little credit being granted for contributions to collaborative work (Kueffer et al. 2011), many scientists avoid becoming involved in complex multidisciplinary projects.

How can this situation be improved? Following the strategy of system optimization, publishing success within the realm of science would remain an important measure of achievement but would be complemented by other metrics related to the societal impact of the research. This could involve assessing publications intended for a nonacademic audience or ensuring that publishing in inter- and transdisciplinary journals enjoys the same status as publishing in mainstream disciplinary journals (Kueffer et al. 2007). Furthermore, skills and types of experience such as team work, inter- and transdisciplinary collaboration, outreach, and pursuing unconventional or highrisk sustainability research projects could be rewarded (COSEPUP 2005, Frodeman et al. 2010).

In contrast, a system innovation strategy might involve broadening the range of academic career options. For some positions, a conventional publication profile will still be important; for others, however, a strong track-record in interand transdisciplinary collaboration, project management, and harnessing scientific knowledge for concrete problem solving will be more important criteria. Such institutions could also create opportunities for more diverse professional experience, with periods spent in industry or public administration being seen as a benefit for, rather than as a hindrance to, an academic career. Possible measures to promote such diversity include nonacademic sabbaticals, staff exchanges with industry, extension professorships for scientists working in applied and nonacademic institutions, and the physical co-location of researchers and external partners.

\section{Expand research funding evaluation and programs}

Research funding agencies can stimulate change by adapting their selection criteria, assessment procedures, and bodies, and by introducing new types of support. Problem-oriented research means a high investment in learning about and taking account of other perspectives relevant to the problem to be solved. Such research processes are typically slow and dependent upon long-term collaborations with external partners; indeed, during the course of a project, it may be necessary to redefine fundamentally the research process to meet the desired goals. A continuity of funding over an extended period is therefore important. To reduce the risk of failure of collaborative projects, funding for the initial problem framing is needed to support participatory processes such as building an interdisciplinary team, stakeholder engagement, and first steps toward a common problem framing, language, and concepts, and building teamwork and mutual trust.

In the case of system optimization, funding agencies add new funding schemes or criteria to existing ones. The U.S. National Science Foundation's Broader Impacts Criterion was introduced in 1997 (Holbrook 2009, 2010). In Switzerland, the National Research Programmes and special divisions for funding international co-operation and interdisciplinary projects of the Swiss National Science Foundation (http:// www.snf.ch/E/Pages/default.aspx) are other examples of novel research funding mechanisms. Increasingly, money is also available for developing the research proposals. In Sweden, the Mistra Foundation calls for participatory development of proposals. In a system innovation scenario, funding structures would no longer be organized along disciplines or academic fields but according to the world's most pressing problems like hunger, migration, climatic change, and biodiversity loss. Furthermore, a system innovation strategy could mean that a sizable part of the funding is distributed by users or recipients of research results and that review boards include representatives of the private and public sectors as well as of civil society.

\section{Provide professional services and training}

Managing inter- and transdisciplinary research with external partners requires not only a particular kind of leadership (Gray 
2008), but also specific skills in project management and communication (Schophaus et al. 2004, Defila et al. 2006, Hollaender et al. 2008). However, it cannot be assumed that academic scientists, especially those trained in disciplinary research, possess these skills to the required degree. Over the past years, a community of researchers engaged in problemoriented research has emerged (Bammer 2005, Kueffer et al. 2007), and there is increasing expertise on good practice for problem-oriented and collaborative research (Scholz and Tietje 2002, COSEPUP 2005, Pohl and Hirsch Hadorn 2007, Dietz and Stern 2008, Hirsch Hadorn et al. 2008, McDonald et al. 2009, Bergmann et al. 2010, Frodeman et al. 2010). Universities can build on this expertise and provide training for faculty, staff, and graduate students in key skills for problem-oriented research and also provide access to professional services. In a system optimization scenario, such supporting services would take up a minor part of university budgets comparable to corporate communications units at many universities. In contrast, in a system innovation scenario, these professional services would become a key element of universities, like technology transfer departments in industry research.

\section{Support new institutional structures}

Universities can facilitate inter- and transdisciplinary collaboration by promoting loose, nonbureaucratic structures that cross main organizational boundaries (COSEPUP 2005, Whitfield 2008, Frodeman et al. 2010). These new structures may be at the level of research groups, institutes, departments, or competence centers, and may be temporary or long term. They need to adopt an adaptive research management and funding cycle because projects vary in the form and intensity of partnerships. Even without new structures, however, universities can do much to promote bottom-up collaboration by facilitating social interactions among scientists from different disciplines. Practical aspects such as how space is allocated and how new buildings are designed can be decisive in this respect (Galison 1999, Whitfield 2008). In the future, new computer and Internet technologies may increasingly allow virtual knowledge-sharing forums to be built. One such example is the CCES Swiss Experiment Platform (http://www. swiss-experiment.ch; Fig. 3).

System optimization means that the existing institutional arrangements are complemented with additional institutional structures. The Swiss Federal Institute of Technology (ETH) in Zurich, for instance, retained its discipline-based institutional organization but created a variety of new institutional structures, including the Department of Environmental Systems Science (http://www.usys.ethz.ch/ index_EN), the Competence Center for Environment and Sustainability (http://www.cces.ethz.ch), the Competence Center Energy and Mobility (http://www.ccem.ch/), ETH sustainability (http://www.sustainability.ethz.ch/index_EN), a former center that facilitated research with developing countries, and a center for the dialog of disciplines (Collegium
Helveticum, http://www.collegium.ethz.ch/). These structures connect traditional disciplinary professorships to facilitate problem-oriented teaching, research, and outreach. In contrast, universities like Leuphana University in Lüneburg, Germany (http://www.leuphana.de/en/home.html), and Arizona State University in USA (http://www.asu.edu/) have pursued the goal of problem-oriented research through system innovation. In doing so, they have created new interdisciplinary departments and appointed staff specifically for their expertise in inter- and transdisciplinary work (Beringer and Adomßent 2008, Crow 2010).

Fig. 3. Diverse measurement technologies and data sets are both needed to understand complex outdoor phenomena. Such interdisciplinary data collection and management activities can promote interdisciplinary thinking and collaborations. The image from Davos, Switzerland, shows the Wannengrat experimental catchment, where avalanche formation, snow deposition, hydrology, and natural hazard management are studied (background), and an advanced radar installation is used by an interdisciplinary team of scientists (foreground). Remote sensing data from radars and ground-based data are integrated with sophisticated data management infrastructure developed through the CCES Swiss Experiment Platform. (Photo: Nicholas Dawes, SLF Davos)

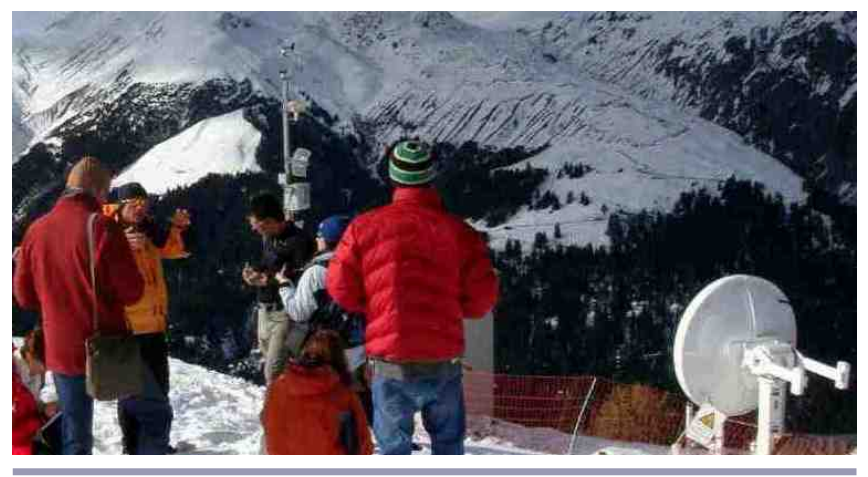

\section{Promote new teaching models and education for inter-} and transdisciplinary skills

New ways of teaching are important in building capacity for problem-oriented research. These include case studies in which students investigate complex, real-world problems, and student projects that are conducted in partnership with societal actors and guided by teachers from two or more disciplines. In the literature about education for sustainability, three strategies are sometimes differentiated: sustainability is taught in specialized courses, sustainability is integrated in existing courses across the curriculum, and the educational system is fundamentally transformed (Sterling 2004, Sherman 2008, Rusinko 2010). The first two represent system optimization approaches, whereas the third is clearly system innovation. 
Examples of the first strategy, specialized courses, are the NSSI case studies (http://www.uns.ethz.ch/translab/index; Fig. 4) and the Massachusetts Institute of Technology S-Lab (http://actionlearning.mit.edu/s-lab), which are designed for students within a particular department and build on real-world problems and mutual learning with stakeholders. They enable training for inter- and transdisciplinary skills and to build confidence to work at the policy-science or managementscience interface (Stauffacher et al. 2006). In addition to team and communication skills, problem-oriented research also asks for specific skills such as the ability to address problems from different perspectives and reflect on the ways different disciplines understand and address a problem (Scholz and Tietje 2002, COSEPUP 2005, Stauffacher et al. 2006, Levin and Martin 2007). An example of the second strategy, integrating sustainability in existing curricula across departments, is university courses that provide access to an introduction to sustainability issues for students from all specializations (Brundiers and Wiek 2011). An interesting model at ETH Zurich is seed sustainability, which is a project platform that facilitates student research on sustainabilityrelated topics (Kueffer 2006, Brundiers and Wiek 2011). Through seed sustainability projects, students from all departments have the opportunity to do their study-related research (theses and dissertations) in interdisciplinary teams and in close collaboration with practice partners from outside academia such as the private sector, public domain, or nongovernmental organizations. Such teaching formats are also important for disseminating research knowledge, for example, through the so-called science shops that couple teaching with scientific consultancy (Hellemans 2001, McNie 2007).

A system innovation strategy structures the curriculum around problems (e.g., food security, biodiversity conservation, sustainable urban planning) and/or environmental systems (e. g., aquatic systems, forests), rather than around disciplines. Such problem-focused degree courses are now offered by many universities, especially at the master's level. However, educational innovation related to sustainability should go beyond an emphasis on practical problems in two important ways. First, students must be provided with the necessary conceptual foundations such as epistemological pluralism, reflexivity, systems thinking, or resilience thinking (Miller et al. 2008, Krasny et al. 2011). Second, as Krasny et al. (2009:2) argue, the aim of such courses should be "to create situations where, through ongoing interactions with the social and ecological elements of the larger system, students develop the capacity to play a meaningful role in shaping their own future and that of their larger community." Thus, engagement with problem solving and society must form a central role in the learning process; the knowledge of faculty, students, and collaborators evolves through the social learning process.
Fig. 4. New forms of teaching are needed to educate a new generation of sustainability experts and foster inter- and transdisciplinary research and partnerships. In a transdisciplinary case study at ETH Zurich (Stauffacher et al. 2006), students work in groups and address real-world problems together with teachers and actors from practice (ETH-UNS TdLab).

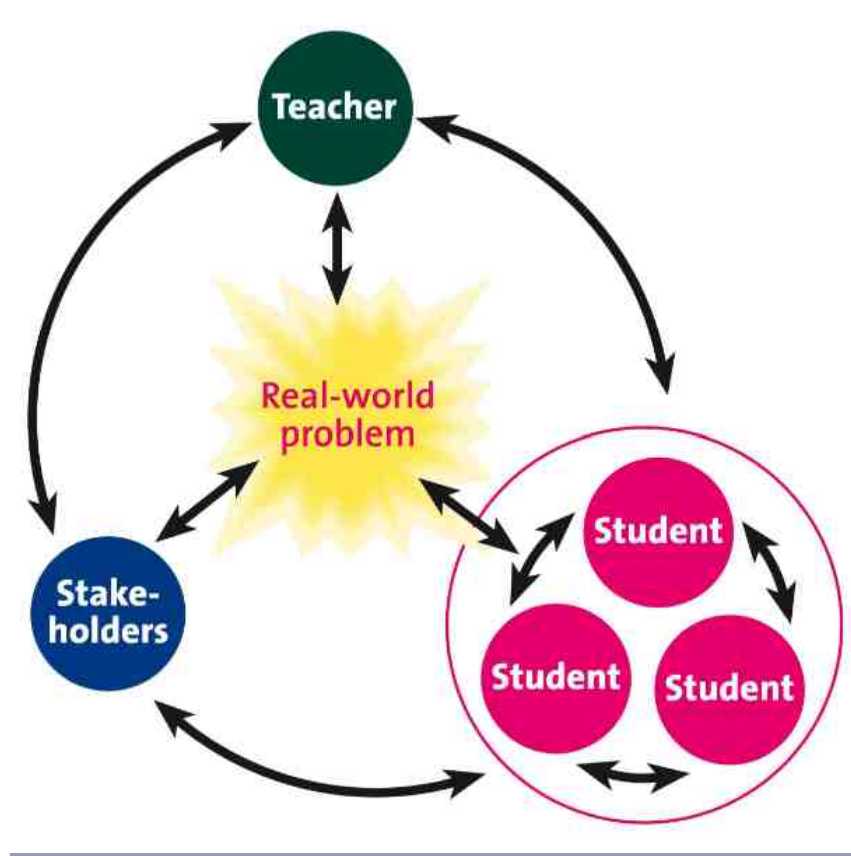

\section{Redefine outreach}

Universities are aware of their responsibility for ensuring that research results reach those who can apply them. Often, however, they attempt to achieve this by presenting the main conclusions in an easily accessible form in newspapers and electronic media or by producing brochures and books aimed at the general public. While these activities are important, they are based on a linear research model in which scientists first produce knowledge that they then disseminate in a form that society can use (Stokes 1997). Thus, outreach is essentially a unidirectional transfer of information. The idea of partnership implies a reciprocal exchange of knowledge and an engagement of universities in civic life (Peters et al. 2008), which has been variously described as mutual learning (Scholz and Tietje 2002), knowledge interfacing and sharing (Roux et al. 2006), knowledge exchange (Fry et al. 2008), and situated and social learning (Checkland 2000, Blackmore 2007, Krasny et al. 2009). It is important to understand that knowledge exchange related to sustainability is more than a simple transfer of information or facts. Such information is underlain by tacit knowledge, a complex mix of theory, experience, assumptions, and values, which is best 
communicated through personal encounters of scientists and practitioners based on mutual trust and transparency (Cash et al. 2003, van Kerkhoff and Lebel 2006, Collins and Evans 2007, Fry et al. 2008, van der Sluijs et al. 2008, Wibeck 2009). Establishing forums or communities of practice that enable regular interactions of scientists and practitioners can be a powerful means of achieving outreach (Wenger 2000, Kueffer 2006, Roux et al. 2006; Fig. 5). Citizen science projects that involve the public in conducting research or collecting data are another promising arena for mutual learning between scientists and the public (e.g., Bonney et al. 2009). However, to be effective, the role of these collaborations in the overall project must be explicitly defined (Stauffacher et al. 2008, Krütli et al. 2010).

Fig. 5. Continuous research partnerships enable reciprocal learning and knowledge exchange between researchers and practitioners and ensure legitimate and salient research and effective outreach. The photograph shows scientists and practitioners at a workshop on future research priorities as part of a 15-yr research collaboration between ETH Zurich, the Ministry of Environment, and several nongovernmental organizations in Seychelles (Western Indian Ocean) on the management of tropical forests and plant conservation. (Photo: Eva Schumacher)

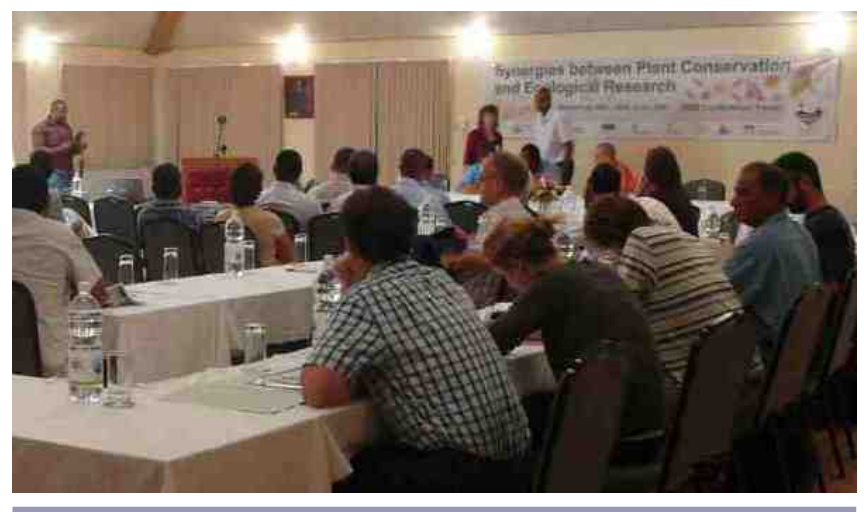

There are several things that universities can do to optimize the relevance and value of the knowledge they produce. First, they can establish boundary organizations that reconcile demand and supply of information between the research institute and the private and public sectors and civil society (Guston 2001, McNie 2007, Sarewitz and Pielke 2007). Such boundary organizations should be able to provide foresight and horizon scanning of future challenges (Sutherland et al. 2011; e.g., UK's Foresight Programme, http://www.bis.gov. uk/foresight/), rapid responses to emerging issues, and continuous support of evidence-based decision making. Second, to respond adequately to rapidly developing issues, universities should develop contingency plans, ensuring that staff can be made available at short notice and that the necessary support services are available. Recent examples of issues requiring rapid responses include disease outbreaks (e. g., SARS, BSE, and avian influenza), natural catastrophes (e. g., hurricane Katrina in USA, the eruption of Eyjafjallajökull in Iceland), and other disasters (e.g., Deepwater Horizon oil spill in the Gulf of Mexico, the 2011 nuclear accident in Fukushima, Japan). Third, universities can help society by supporting academic activities such as review and synthesis. Research related to sustainability can have much greater impact if the results are systematically synthesized, interpreted, and validated for policy makers in the form of systematic reviews and meta-analytic processes (Sutherland et al. 2004). An example of professional assistance for such systematic reviews is the UK Collaboration for Environmental Evidence (http://www.environmentalevidence.org).

According to a system innovation perspective, outreach is the central part of research and teaching at universities and research institutes. It thus becomes a continuous engagement of everyday academic work with the needs of civil society and the private and public sectors as a standard element of teaching and research activities. This is better termed situated and social learning (Checkland 2000, Blackmore 2007, Krasny et al. 2009, Krasny et al. 2011). Examples are the transdisciplinary case studies at ETH Zurich (Fig. 4) or courses in the Swedish University of Agricultural Sciences Master's program (Krasny et al. 2009), in which students, faculty, and stakeholders jointly deal with concrete real-world problems and thereby induce a mutual learning process.

\section{CONCLUSIONS: BALANCING SYSTEM OPTIMIZATION AND SYSTEM INNOVATION IN THE TRANSFORMATION OF ACADEMIC INSTITUTIONS}

In a period of rapid environmental, economic, and political change, academic institutions are facing unprecedented challenges. It is increasingly accepted that the link between producing and applying knowledge must become more direct; indeed, many scientists and policy makers have called for changes of the kind we advocate here: more interdisciplinarity, more partnerships, and better problem orientation. Throughout the world, universities are questioning their current approaches and experimenting with new structures and methods in research and education.

An important lesson from the literature of transition management is that these transitions are learning-by-doing processes that are evolutionary and demand a multi-level approach. We see much value in a view of change that emphasizes the complementarity of system innovation and system optimization (March 1991, Rotmans et al. 2001). Thus, some circumstances may benefit from radically new ideas and broad visions, which are the basis for system innovation, whereas in others, it may be better to optimize existing structures through a series of small steps (Rotmans et al. 2001). 
Clearly, the most appropriate strategy in any particular case will depend on the specific context and the trade-offs that are involved (e.g., March 1991, Moore and Westley 2011). However, there is much that universities can learn from each other as they attempt to adapt to a rapidly changing world. For example, linking institutions that follow a system optimization approach with institutions that opt for system innovation could be a useful way to optimize the costs and benefits of the contrasting approaches. Equally, universities may attempt to follow a system optimization approach in one field of activity (e.g., research) while pushing for system innovation in another (e.g., teaching). However, the goal for all institutions must be a process of change that preserves the traditional strengths of academic research, with its emphasis on disciplinary excellence and intra-scientific rigor, while ensuring that institutional environments and the skills, worldviews, and experiences of the involved actors adapt to the rapidly changing needs of society.

In recent years, there has been a vigorous debate about how universities can respond more effectively to the challenges of sustainability. We have summarized some of the key ideas and notions in this debate, with the aim of encouraging learning and consensus building among scientists, experts on new research practices, and university administrators. We hope that universities will be encouraged to take practical steps along the lines suggested and monitor their effectiveness. This will require sophisticated evaluation criteria and procedures that account for the multi-causality, multi-level hierarchical structure, and context-dependence of innovation processes (Chen and Rossi 1980, Chen 1996). Developing appropriate means for assessing outcomes of institutional change at universities will therefore be an important avenue for future research.

Responses to this article can be read online at: http://www.ecologyandsociety.org/issues/responses. php/5045

\section{Acknowledgments:}

The paper is based on a workshop held by the Alliance for Global Sustainability at ETH Zurich on October 15-16, 2009. The workshop was hosted by the ETH Domain Competence Center for Environment and Sustainability (CCES) together with ETH Sustainability. The paper is not a consensus document but presents the conclusions and recommendations of the authors based on the workshop's outcome. We thank the editors and reviewers for very helpful comments on an earlier version.

\section{LITERATURE CITED}

Bagamoyo College of Arts, Tanzania Theatre Centre, R. Mabala, and K. B. Allen. 2002. Participatory action research on HIV/AIDS through a popular theatre approach in Tanzania. Evaluation and Program Planning 25(4):333-339. http://dx. doi.org/10.1016/S0149-7189(02)00044-7

Bammer, G. 2005. Integration and implementation sciences: building a new specialization. Ecology and Society 10(2): 6. [online] URL: http://www.ecologyandsociety.org/vol10/iss2/ art6/.

Barreteau, O., P. W. G. Bots, and K. A. Daniell. 2010. A framework for clarifying "participation" in participatory research to prevent its rejection for the wrong reasons. Ecology and Society 15(2): 1. [online]. URL: http://www. ecologyandsociety.org/vol15/iss2/art1/.

Becker, E., T. Jahn, and E. Stiess. 1999. Exploring uncommon ground: sustainability and the social sciences. Pages 1-22 in E. Becker and T. Jahn, editors. Sustainability and the social sciences: a cross-disciplinary approach to integrating environmental considerations into theoretical reorientation. Zed Books, London, UK.

Bergmann, M., T. Jahn, T. Knobloch, W. Krohn, C. Pohl, and E. Schramm. 2010. Methoden transdisziplinärer Forschung: ein Überblick mit Anwendungsbeispielen. Campus Verlag, Frankfurt am Main, Germany.

Beringer, A., and M. Adomßent. 2008. Sustainable university research and development: inspecting sustainability in higher education research. Environmental Education Research 14 (6):607-623. http://dx.doi.org/10.1080/13504620802464866

Blackmore, C. 2007. What kinds of knowledge, knowing and learning are required for addressing resource dilemmas?: a theoretical overview. Environmental Science and Policy 10 (6):512-525. http://dx.doi.org/10.1016/j.envsci.2007.02.007

Bonney, R., C. B. Cooper, J. Dickinson, S. Kelling, T. Phillips, K. V. Rosenberg, and J. Shirk. 2009. Citizen science: a developing tool for expanding science knowledge and scientific literacy. BioScience 59(11):977-984. http://dx.doi. org/10.1525/bio.2009.59.11.9

Brewer, G. D. 1999. The challenges of interdisciplinarity. Policy Sciences 32(4):327-337. http://dx.doi.org/10.1023/ A:1004706019826

Brundiers, K., and A. Wiek. 2011. Educating students in realworld sustainability research: vision and implementation. Innovative Higher Education 36(2):107-124. http://dx.doi. org/10.1007/s10755-010-9161-9

Carpenter, S. R., C. Folke, M. Scheffer, and F. R. Westley. 2009. Resilience: accounting for the noncomputable. Ecology and Society 14(1): 13. [online] URL: http://www. ecologyandsociety.org/vol14/iss1/art13/. 
Cash, D. W., W. C. Clark, F. Alcock, N. M. Dickson, N. Eckley, D. H. Guston, J. Jäger, and R. B. Mitchell. 2003. Knowledge systems for sustainable development. Proceedings of the National Academy of Sciences 100(14):8086-8091. http://dx.doi.org/10.1073/pnas.1231332100

Chapin, F. S. III, M. E. Power, S. T. A. Pickett, A. Freitag, J. A. Reynolds, R. B. Jackson, D. M. Lodge, C. Duke, S. L. Collins, A. G. Power, and A. Bartuska. 2011. Earth stewardship: science for action to sustain the human-earth system. Ecosphere 2(8):art89. http://dx.doi.org/10.1890/ ES11-00166.1

Checkland, P. 2000. Soft systems methodology: a thirty year retrospective. Systems Research and Behavioral Science 17 (S1):S11-S58. http://dx.doi.org/10.1002/1099-1743(200011) $17: 1+<:: A I D-S R E S 374>3.3 . C O ; 2-F$

Chen, H.-T. 1996. A comprehensive typology for program evaluation. Evaluation Practice 17(2):121-130. http://dx.doi. org/10.1016/S0886-1633(96)90017-3

Chen, H.-T., and P. H. Rossi. 1980. The multi-goal, theorydriven approach to evaluation: a model linking basic and applied social science. Social Forces 59(1):106-122. http://dx. doi.org/10.1093/sf/59.1.106

Collins, H., and R. Evans. 2007. Rethinking expertise. University of Chicago Press, Chicago, Illinois, USA.

Committee on Science, Engineering, and Public Policy (COSEPUP). 2005. Facilitating interdisciplinary research. National Academies Press, Washington, D.C., USA. [online] URL: http://www.nap.edu/openbook.php?isbn=0309094356.

Cook, C. N., M. Hockings, and R. W. Carter. 2010. Conservation in the dark? The information used to support management decisions. Frontiers in Ecology and Environment 8(4):181-186. http://dx.doi.org/10.1890/090020

Costanza, R. 2003. A vision of the future of science: reintegrating the study of humans and the rest of nature. Futures 35(6):651-671. http://dx.doi.org/10.1016/S0016-3287 (02)00105-2

Crow, M. M. 2010. Organizing teaching and research to address the grand challenges of sustainable development. BioScience 60(7):488-489. http://dx.doi.org/10.1525/bio.2010.60.7.2

Defila, R., A. Di Giulio, and M. Scheuermann. 2006. Forschungsverbundmanagement - Handbuch für die Gestaltung inter- und transdisziplinärer Projekte. Vdf Hochschulverlag, Zurich, Switzerland.

Dietz, T., and P. C. Stern, editors. 2008. Public participation in environmental assessment and decision making. National Academies Press, Washington, D.C., USA.
Donovan, C. 2007. The qualitative future of research evaluation. Science and Public Policy 34(8):585-597. http:// dx.doi.org/10.3152/030234207X256538

Eigenbrode, S. D., M. O'Rourke, J. D. Wulfhorst, D. M. Althoff, C. S. Goldberg, K. Merrill, W. Morse, M. NielsenPincus, J. Stephens, L. Winowiecki, and N. A. Bosque-Pérez. 2007. Employing philosophical dialogue in collaborative science. BioScience 57(1):55-64.

Elzinga, A. 2008. Participation. Pages 345-359 in G. Hirsch Hadorn, H. Hoffmann-Riem, S. Biber-Klemm, W. Grossenbacher-Mansuy, D. Joye, C. Pohl, U. Wiesmann, and E. Zemp, editors. Handbook of transdisciplinary research. Springer, Heidelberg, Germany.

Evely, A. C., I. Fazey, M. Pinard, and X. Lambin. 2008. The influence of philosophical perspectives in integrative research: a conservation case study in the Cairngorms National Park. Ecology and Society 13(2): 52. [online] URL: http:// www.ecologyandsociety.org/vol13/iss2/art52/.

Ferrer-Balas, D., R. Lozano, D. Huisingh, H. Buckland, P. Ysern, and G. Zilahy. 2010. Going beyond the rhetoric: system-wide changes in universities for sustainable societies. Journal of Cleaner Production 18(7):607-610. http://dx.doi. org/10.1016/j.jclepro.2009.12.009

Frodeman, R., J. Thompson Klein, and C. Mitcham, editors. 2010. The Oxford handbook of interdisciplinarity. Oxford University Press, Oxford, UK.

Fry, P., F. Bachmann, L. Bose, M. Flury, R. Förster, A. Kläy, C. Kueffer, and C. Zingerli. 2008. Von implizitem Know-how $\mathrm{zu}$ expliziten Thesen. Inter- und transdisziplinärer Wissensaustausch. Gaia 17:318-320.

Funtowicz, S. O., and J. R. Ravetz. 1993. Science for the postnormal age. Futures 25(7):739-755. http://dx.doi. org/10.1016/0016-3287(93)90022-L

Galison, P. 1999. Trading zone. Coordinating action and belief. Pages 137-160 in M. Biagioli, editor. The science studies reader. Routledge, New York, New York, USA.

Gallopín, G. C., S. Funtowicz, M. O’Connor, and J. Ravetz. 2002. Science for the twenty-first century: from social contract to the scientific core. International Social Science Journal 53 (168):219-229.

Gibbons, M., C. Limoges, H. Nowotny, M. Trow, P. Scott, and S. Schwartzman. 1994. The new production of knowledge: the dynamics of science and research in contemporary societies. Sage, Thousand Oaks, California, USA.

Giller, K. E., C. Leeuwis, J. A. Andersson, W. Andriesse, A. Brouwer, P. Frost, P. Hebinck, I. Heitkönig, M. K. van Ittersum, N. Koning, R. Ruben, M. Slingerland, H. Udo, T. 
Veldkamp, C. van de Vijver, M. T. van Wijk, and P. Windmeijer. 2008. Competing claims on natural resources: what role for science? Ecology and Society 13(2): 34. [online] URL: http://www.ecologyandsociety.org/vol13/iss2/art34/.

Giri, A. K. 2002. The calling of a creative transdisciplinarity. Futures 34(1):103-115. http://dx.doi.org/10.1016/S0016-3287 (01)00038-6

Gray, B. 2008. Enhancing transdisciplinary research through collaborative leadership. American Journal of Preventive Medicine 35(S2):S124-S132. http://dx.doi.org/10.1016/j. amepre.2008.03.037

Groffman, P. M., editor. 2010. Special issue: effective communication of science in environmental controversies. Frontiers in Ecology and Environment 8(6):284-328.

Gross, M. 2010. Ignorance and surprise: science, society, and ecological design. MIT Press, Cambridge, Massachusetts, USA.

Grunwald, A. 2004. Strategic knowledge for sustainable development: the need for reflexivity and learning at the interface between science and society. International Journal of Foresight and Innovation Policy 1(1-2):150-167. http://dx. doi.org/10.1504/IJFIP.2004.004619

Gunderson, L. H., and C. S. Holling, editors. 2002. Panarchy: understanding transformations in human and natural systems. Island Press, Washington, D.C., USA.

Guston, D. H. 2001. Boundary organizations in environmental policy and science: an introduction. Science, Technology \& Human Values 26(4):399-408. http://dx.doi.org/10.1177/016224390102600401

Harremoës, P., D. Gee, M. MacGarvin, A. Stirling, J. Keys, B. Wynne, and S. Guedes Vaz, editors. 2001. Late lessons from early warnings: the precautionary principle 1896-2000. European Environment Agency, Copenhagen, Denmark.

Hellemans, A. 2001. Science shops provide non-profit alternative. Nature 412:4-5.

Hirsch, G. 1995. Beziehungen zwischen Umweltforschung und disziplinärer Forschung. Gaia 4:302-314.

Hirsch Hadorn, G., H. Hoffmann-Riem, S. Biber-Klemm, W. Grossenbacher-Mansuy, D. Joye, C. Pohl, U. Wiesmann, and E. Zemp, editors. 2008. Handbook of transdisciplinary research. Springer, Heidelberg, Germany.

Hoffmann-Riem, H., and B. Wynne. 2002. In risk assessment, one has to admit ignorance. Nature 416:123. http://dx.doi. org/10.1038/416123a

Holbrook, J. B. 2009. Editor's introduction. Social Epistemology 23(3-4):177-181. http://dx.doi.org/10.1080/02$\underline{691720903438169}$
Holbrook, J. B. 2010. The use of societal impacts considerations in grant proposal peer review: a comparison of five models. Technology and Innovation 12(3):213-224. http:// dx.doi.org/10.3727/194982410X12895770314078

Hollaender, K., M. C. Loibl, and A. Wilts. 2008. Management. Pages 383-395 in G. Hirsch Hadorn, H. Hoffmann-Riem, S. Biber-Klemm, W. Grossenbacher-Mansuy, D. Joye, C. Pohl, U. Wiesmann, and E. Zemp, editors. Handbook of transdisciplinary research. Springer, Heidelberg, Germany. http://dx.doi.org/10.1007/978-1-4020-6699-3_25

Holling, C. S., editor. 1978. Adaptive environmental assessment and management. Wiley, New York, New York, USA.

Hubert, B., M. Meuret, and J. Bonnemaire. 2008. Shepherds, sheep and forest fires: a reconception of grazingland management. Pages 103-126 in G. Hirsch Hadorn, H. Hoffmann-Riem, S. Biber-Klemm, W. GrossenbacherMansuy, D. Joye, C. Pohl, U. Wiesmann, and E. Zemp, editors. Handbook of transdisciplinary research. Springer, Heidelberg, Germany. http://dx.doi.org/10.1007/978-1-4020-6699-3 7

Huutoniemi, K. 2010. Evaluating interdisciplinary research. Pages 309-320 in R. Frodeman, J. T. Klein, and K. Mitcham, editors. Oxford handbook of interdisciplinarity. Oxford University Press, Oxford, UK.

Intergovernmental Panel on Climate Change (IPCC). 2007. IPCC fourth assessment report: climate change 2007 (AR4). Synthesis report. Intergovernmental Panel on Climate Change, Geneva, Switzerland. [online] URL: http://www.ipcc.ch/ publications_and_data/ar4/syr/en/contents.html.

International Council for Science (ICSU). 2010. Earth system science for global sustainability: the grand challenges. International Council for Science, Paris, France. [online] URL: http://www.icsu.org/publications/reports-and-reviews/ grand-challenges/GrandChallenges_Oct2010.pdf.

Jacobs, J. A., and S. Frickel. 2009. Interdisciplinarity: a critical assessment. Annual Review of Sociology 35:43-65. http://dx. doi.org/10.1146/annurev-soc-070308-115954

Jasanoff, S. 2007. Technologies of humility. Nature 450:33. http://dx.doi.org/10.1038/450033a

Kates, R. W., W. C. Clark, R. Corell, J. M. Hall, C. C. Jaeger, I. Lowe, J. J. McCarthy, H. J. Schellnhuber, B. Bolin, N. M. Dickson, S. Faucheux, G. C. Gallopin, A. Grübler, B. Huntley, J. Jäger, N. S. Jodha, R. E. Kasperson, A. Mabogunje, P. Matson, H. Mooney, B. Moore III, T. O'Riordan, and U. Svedlin. 2001. Sustainability science. Science 292:641-642. http://dx.doi.org/10.1126/science.1059386

Khagram, S., K. A. Nicholas, D. M. Bever, J. Warren, E. H. Richards, K. Oleson, J. Kitzes, R. Katz, R. Hwang, R. Goldman, J. Funk, and K. A. Brauman. 2010. Thinking about 
knowing: conceptual foundations for interdisciplinary environmental research. Environmental Conservation 37 (4):388-397. http://dx.doi.org/10.1017/S0376892910000809

Kitcher, P. 2010. The climate change debates. Science 328:1230-1234. http://dx.doi.org/10.1126/science.1189312

Klein, J. T. 2008. Evaluation of interdisciplinary and transdisciplinary research: a literature review. American Journal of Preventive Medicine 35(2S):S116-S123. http://dx. doi.org/10.1016/j.amepre.2008.05.010

Klein, J. T., W. Grossenbacher-Mansuy, R. Häberli, A. Bill, R. W. Scholz, and M. Welti, editors. 2001. Transdisciplinarity: joint problem solving among science, technology, and society: an effective way for managing complexity. Birkhäuser, Basel, Switzerland.

Krasny, M. E., C. Lundholm, and R. Plummer, editors. 2011. Resilience in social-ecological systems: the role of learning and education. Routledge, Boston, Massachusetts, USA.

Krasny, M. E., K. G. Tidball, and N. Sriskandarajah. 2009. Education and resilience: social and situated learning among university and secondary students. Ecology and Society 14(2): 38. [online] URL: http://www.ecologyandsociety.org/vol14/ iss $2 / \operatorname{art} 38 /$.

Kriebel, D., J. Tickner, P. Epstein, J. Lemons, R. Levins, E. L. Loechler, M. Quinn, R. Rudel, T. Schettler, and M. Stoto. 2001. The precautionary principle in environmental science. Environmental Health Perspectives 109:871-876.

Krütli, P., M. Stauffacher, T. Flüeler, and R. W. Scholz. 2010. Functional-dynamic public participation in technological decision-making: site selection processes of nuclear waste repositories. Journal of Risk Research 13(7):861-875. http:// dx.doi.org/10.1080/13669871003703252

Kueffer, C. 2006. Integrative ecological research: casespecific validation of ecological knowledge for environmental problem solving. Gaia 15:115-120.

Kueffer, C. 2010. Transdisciplinary research is needed to predict plant invasions in an era of global change. Trends in Ecology and Evolution 25(11):619-620. http://dx.doi. org/10.1016/j.tree.2010.08.001

Kueffer, C., and G. Hirsch Hadorn. 2008. How to achieve effectiveness in problem-oriented landscape research: the example of research on biotic invasions. Living Reviews in Landscape Research 2: 2. [online] URL: http://www. livingreviews.org/lrlr-2008-2.

Kueffer, C., G. Hirsch Hadorn, G. Bammer, L. van Kerkhoff, and C. Pohl. 2007. Towards a publication culture in transdisciplinary research. Gaia 16:22-26.

Kueffer, C., Ü. Niinemets, R. E. Drenovsky, J. Kattge, P. Milberg, H. Poorter, P. B. Reich, C. Werner, M. Westoby, and
I. J. Wright. 2011. Fame, glory and neglect in meta-analyses. Trends in Ecology and Evolution 26(10):493-494. http://dx. doi.org/10.1016/j.tree.2011.07.007

Levin, M., and A. W. Martin. 2007. The praxis of educating action researchers: the possibilities and obstacles in higher education. Action Research 5(3):219-229. http://dx.doi. org/10.1177/1476750307081014

Levin, S., and W. Clark, editors. 2010. Toward a science of sustainability: report from toward a science of sustainability conference. CID Working Paper 196. Harvard University, Cambridge, Massachusetts, USA. [online] URL: http://www. hks.harvard.edu/centers/cid/publications/faculty-working-papers/ cid-working-paper-no.-196.

Loibl, M. C. 2006. Integrating perspectives in the practice of transdisciplinary research. Pages 294-309 in J.-P. Voss, D. Bauknecht, and R. Kemp, editors. Reflexive governance for sustainable development. Edward Elgar, Cheltenham, UK.

Lowe, P., G. Whitman, and J. Phillipson. 2009. Ecology and the social sciences. Journal of Applied Ecology 46(2):297-305. http://dx.doi.org/10.1111/j.1365-2664.2009.01621.x

Lubchenco, J. 1998. Entering the century of the environment: a new social contract for science. Science 279:491-497. http:// dx.doi.org/10.1126/science.279.5350.491

March, J. G. 1991. Exploration and exploitation in organizational learning. Organization Science 2(1):71-87. http://dx.doi.org/10.1287/orsc.2.1.71

McDonald, D., G. Bammer, and P. Deane. 2009. Research integration using dialogue methods. ANU ePress, Canberra, Australia. [online] URL: http://epress.anu.edu.au?p=60381.

McIntyre, B. D., H. R. Herren, J. Wakhungu, and R. T. Watson, editors. 2009. Agriculture at a crossroads: synthesis report. Island Press, Washington, D.C., USA.

McMichael, A. J., C. D. Butler, and C. Folke. 2003. New visions for addressing sustainability. Science 302:1919-1920.

McNie, E. C. 2007. Reconciling the supply of scientific information with user demands: an analysis of the problem and review of the literature. Environmental Science and Policy 10(1):17-38. http://dx.doi.org/10.1016/j.envsci.2006.10.004

Michaels, D. 2008. Doubt is their product: how industry's assault on science threatens your health. Oxford University Press, Oxford, UK.

Millennium Ecosystem Assessment. 2005. Ecosystems and human well-being: synthesis. Island Press, Washington, D.C., USA. [online] URL: http://www.millenniumassessment.org/ documents/document.356.aspx.pdf.

Miller, T. R., T. D. Baird, C. M. Littlefield, G. Kofinas, F. S. Chapin III, and C. L. Redman. 2008. Epistemological 
pluralism: reorganizing interdisciplinary research. Ecology and Society 13(2): 46. [online] URL: http://www. ecologyandsociety.org/vol13/iss2/art46/.

Moore, M.-L., and F. Westley. 2011. Surmountable chasms: networks and social innovation for resilient systems. Ecology and Society 16(1): 15. [online] URL: http://www. ecologyandsociety.org/vol16/iss1/art15/.

Nightingale, P., and A. Scott. 2007. Peer review and the relevance gap: ten suggestions for policy-makers. Science and Public Policy 34(8):543-553. http://dx.doi.org/10.3152/030$\underline{234207 X 254396}$

Nowotny, H., P. Scott, and M. Gibbons. 2001. Re-thinking science: knowledge and the public in an age of uncertainty. Polity Press, Cambridge, UK.

Oreskes, N., and E. M. Conway. 2010. Merchants of doubt: how a handful of scientists obscured the truth on issues from tobacco smoke to global warming. Bloomsbury Press, New York, New York, USA.

Peters, S. J., T. R. Alter, and N. Schwartzbach. 2008. Unsettling a settled discourse: faculty views of the meaning and significance of the land-grant mission. Journal of Higher Education Outreach and Engagement 12(2):33-66.

Pielke, Jr., R. A. 2007. The honest broker: making sense of science in policy and politics. Cambridge University Press, Cambridge, UK.

Plowright, R. K., S. H. Sokolow, M. E. Gorman, P. Daszak, and J. E. Foley. 2008. Causal inference in disease ecology: investigating ecological drivers of disease emergence. Frontiers in Ecology and Environment 6(8):420-429. http:// dx.doi.org/10.1890/070086

Pohl, C. 2005. Transdisciplinary collaboration in environmental research. Futures 37(10):1159-1178. http://dx. doi.org/10.1016/j.futures.2005.02.009

Pohl, C. 2011. What is progress in transdisciplinary research? Futures 43(6):618-626. http://dx.doi.org/10.1016/j.

futures.2011.03.001

Pohl, C., and G. Hirsch Hadorn. 2007. Principles for designing transdisciplinary research. Oekom, Munich, Germany.

Pohl, C., S. Rist, A. Zimmermann, P. Fry, G. S. Gurung, F. Schneider, C. Ifejika Speranza, B. Kiteme, S. Boillat, E. Serrano, G. Hirsch Hadorn, and U. Wiesmann. 2010. Researchers' roles in knowledge co-production: experience from sustainability research in Kenya, Switzerland, Bolivia and Nepal. Science and Public Policy 37(4):267-281. http:// dx.doi.org/10.3152/030234210X496628

ProClim. 1997. Research on sustainability and global change: visions in science policy by Swiss researchers. ProClim, Berne, Switzerland.
Pullin, A. S., T. M. Knight, D. A. Stone, and K. Charman. 2004. Do conservation managers use scientific evidence to support their decision-making? Biological Conservation 119 (2):245-252. http://dx.doi.org/10.1016/j.biocon.2003.11.007

Raven, P. H. 2002. Science, sustainability, and the human prospect. Science 297:954-958. http://dx.doi.org/10.1126/ science.297.5583.954

Rayner, S., and E. L. Malone, editors. 1998. Human choice and climate change. Battelle Press, Columbus, Ohio, USA.

Rhoten, D., and A. Parker. 2004. Risks and rewards of an interdisciplinary research path. Science 306:2046. http://dx. doi.org/10.1126/science. 1103628

Rittel, H. W. J., and M. M. Webber. 1973. Dilemmas in a general theory of planning. Policy Sciences 4(2):155-169. http://dx.doi.org/10.1007/BF01405730

Rotmans, J., R. Kemp, and M. van Asselt. 2001. More evolution than revolution: transition management in public policy. Foresight 3(1):15-31. http://dx.doi.org/10.1108/1463$\underline{6680110803003}$

Roux, D. J., K. H. Rogers, H. C. Biggs, P. J. Ashton, and A. Sergeant. 2006. Bridging the science-management divide: moving from unidirectional knowledge transfer to knowledge interfacing and sharing. Ecology and Society 11(1): 4. [online] URL: http://www.ecologyandsociety.org/vol1/iss11/art4/.

Rusinko, C. A. 2010. Integrating sustainability in higher education: a generic matrix. International Journal of Sustainability in Higher Education 11(3):250-259. http://dx. doi.org/10.1108/14676371011058541

Samarasekera, I. V. 2009. Universities need a new social contract. Nature 462:160-161. http://dx.doi.org/10.1038/462160a

Sarewitz, D. 2004. How science makes environmental controversies worse. Environmental Science and Policy 7 (5):385-403. http://dx.doi.org/10.1016/j.envsci.2004.06.001

Sarewitz, D., and R. A. Pielke, Jr. 2007. The neglected heart of science policy: reconciling supply of and demand for science. Environmental Science and Policy 10(1):5-16. http:// dx.doi.org/10.1016/j.envsci.2006.10.001

Schelling, E., K. Wyss, C. Diguimbaye, M. Béchir, M. Ould Taleb, B. Bonfoh, M. Tanner, and J. Zinsstag. 2008. Towards integrated and adapted health services for nomadic pastoralists and their animals: a north-south partnership. Pages 277-291 in G. Hirsch Hadorn, H. Hoffmann-Riem, S. Biber-Klemm, W. Grossenbacher-Mansuy, D. Joye, C. Pohl, U. Wiesmann, and E. Zemp, editors. Handbook of transdisciplinary research. Springer, Heidelberg, Germany. http://dx.doi. org/10.1007/978-1-4020-6699-3_17 
Schellnhuber, H. J. 1999. 'Earth system' analysis and the second Copernican revolution. Nature 402:C19-C23. http:// dx.doi.org/10.1038/35011515

Schneidewind, U. 2009. Nachhaltige Wissenschaft: Plädoyer für einen Klimawandel im deutschen Wissenschafts- und Hochschulsystem. Metropolis, Marburg, Germany.

Scholz, R. W., and O. Tietje. 2002. Embedded case study methods: integrating quantitative and qualitative knowledge. Sage, Thousand Oaks, California, USA.

Schophaus, M., S. Schön, and H.-L. Dienel. 2004. Transdisziplinäres Kooperationsmanagement. Oekom, Munich, Germany.

Schwarzenbach, R.P., T.Egli, T. B. Hofstetter, U. von Gunten, and B. Wehrli. 2010. Global water pollution and human health. Annual Review of Environment and Resources 35:109-136. http://dx.doi.org/10.1146/annurev-environ-100809-125342

Shanley, P., and C. López. 2009. Out of the loop: why research rarely reaches policy makers and the public and what can be done. Biotropica 41(5):535-544. http://dx.doi.org/10.1111/ j.1744-7429.2009.00561.x

Sherman, D. J. 2008. Sustainability: What's the big idea? A strategy for transforming the higher education curriculum. Sustainability: The Journal of Record 1(3):188-195.

Shrader-Frechette, K. S., and E. D. McCoy. 1993. Method in ecology: strategies for conservation. Cambridge University Press, Cambridge, UK.

Simiyu, K., A. S. Daar, and P. A. Singer. 2010. Stagnant health technologies in Africa. Science 330:1483-1484. http://dx.doi. org/10.1126/science.1195401

Stauffacher, M., T. Flüeler, P. Krütli, and R. W. Scholz. 2008. Analytic and dynamic approach to collaboration: a transdisciplinary case study on sustainable landscape development in a Swiss prealpine region. Systemic Practice and Action Research 21(6):409-422. http://dx.doi.org/10.1007/ s11213-008-9107-7

Stauffacher, M., A. I. Walter, D. J. Lang, A. Wiek, and R. W. Scholz. 2006. Learning to research environmental problems from a functional socio-cultural constructivism perspective: the transdisciplinary case study approach. International Journal of Sustainability in Higher Education 7(3):252-275. http://dx.doi.org/10.1108/14676370610677838

Stephens, J. C., and A. C. Graham. 2010. Toward an empirical research agenda for sustainability in higher education: exploring the transition management framework. Journal of Cleaner Production 18(7):611-618. http://dx.doi.org/10.1016/ j.jclepro.2009.07.009

Sterling, S. 2004. Higher education, sustainability, and the role of systemic learning. Pages 49-70 in P. B. Corcoran and A. E.
J. Wals, editors. Higher education and the challenge of sustainability: problematics, promise, and practice. Kluwer Academic, Dordrecht, The Netherlands. http://dx.doi. org/10.1007/0-306-48515-X_5

Stokes, D. E. 1997. Pasteur's quadrant: basic science and technological innovation. Brookings Institution Press, Washington, D.C., USA.

Stoll-Kleemann, S., and C. Pohl, editors. 2007. Evaluation inter- und transdisziplinärer Forschung: Humanökologie und Nachhaltigkeitsforschung auf dem Prüfstand. Oekom, Munich, Germany.

Strang, V. 2009. Integrating the social and natural sciences in environmental research: a discussion paper. Environment, Development and Sustainability 11(1):1-18. http://dx.doi. org/10.1007/s10668-007-9095-2

Sutherland, W. J., E. Fleishman, M. B. Mascia, J. Pretty, and M. A. Rudd. 2011. Methods for collaboratively identifying research priorities and emerging issues in science and policy. Methods in Ecology and Evolution 2(3):238-247. http://dx. doi.org/10.1111/j.2041-210X.2010.00083.X

Sutherland, W. J., A. S. Pullin, P. M. Dolman, and T. M. Knight. 2004. The need for evidence-based conservation. Trends in Ecology and Evolution 19(6):305-308. http://dx.doi. org/10.1016/j.tree.2004.03.018

Thompson, J. L. 2009. Building collective communication competence in interdisciplinary research teams. Journal of Applied Communication Research 37(3):278-297. http://dx. doi.org/10.1080/00909880903025911

World Water Assessment Programme (WWAP). 2009. Water in a changing world: world water development report 3. UNESCO, Paris, France. [online] URL: http://www.unesco. org/new/en/natural-sciences/environment/water/wwap/wwdr/ wwdr3-2009/downloads-wwdr3/

van der Sluijs, J. P., A. C. Petersen, P. H. M. Janssen, J. S. Risbey, and J. R. Ravetz. 2008. Exploring the quality of evidence for complex and contested policy decisions. Environmental Research Letters 3(2): 024008. http://dx.doi. org/10.1088/1748-9326/3/2/024008

van Kerkhoff, L., and L. Lebel. 2006. Linking knowledge and action for sustainable development. Annual Review of Environment and Resources 31:445-477. http://dx.doi. org/10.1146/annurev.energy.31.102405.170850

Wenger, E. 2000. Communities of practice and social learning systems. Organization 7(2):225-246. http://dx.doi. org/10.1177/135050840072002

Whitfield, J. 2008. An indifference to boundaries. Nature 451:872-873. http://dx.doi.org/10.1038/451872a 
Wibeck, V. 2009. Communicating uncertainty: models of communication and the role of science in assessing progress towards environmental objectives. Journal of Environmental Policy and Planning 11(2):87-102. http://dx.doi. org/10.1080/15239080902891285

World Commission on Environment and Development. 1987. Our common future. Oxford University Press, Oxford, UK.

Wuelser, G., C. Pohl, and G. Hirsch Hadorn. 2012. Structuring complexity for tailoring research contributions to sustainable development: a framework. Sustainability Science 7(1):81-93. http://dx.doi.org/10.1007/s11625-011-0143-3 